\section{Religion and Christianity}

SIR - It is rather unfair of Arno Arrak to criticize Brian Josephson's "concept of religion as an attempt to maximize human goodness" by pointing to the doctrinal extravagances engaged in, in the name of religion, by the Aztecs and Carthaginians (Nature 364, 276; 1993). It is not Quetzalcoatl, Moloch, or even the Buddha that is foremost in Josephson's thoughts. Josephson may use the word religion but what he means is Christianity, where human sacrifice is known to be frowned on. Arrak is on firmer ground when he points out that the "sine qua non of any religion is the existence of supernatural forces".

Josephson writes (Nature 362, 583; 1993) of the "function and fruitfulness" of religious (that is, Christian) belief. Functionally speaking then, what is the precise purpose (or Purpose) of the gods (in general or his own one in particular)? And whose purpose is served? Just what "fruitfulness" is in question, and whose fruitfulness is being addressed when scientists plump for superstition and irrationality and against the scientific approach to matters of reality, factuality and truth?

If we are frightened of the dark that awaits us then let us at least have the courage, and the honesty, to say so. If we must invent gods to grant us eternal life then let us have the moral integrity to say that this is what we are doing, and why.

Let us avoid the humbug, selfdeception and philosophical cant with which we camouflage our terrors and hide our spiritual deceits from ourselves and from others and call this religion.

\section{Ralph Estling}

The Old Parsonage,

Dowlish Wake,

IIminster, Somerset TA19ONY, UK

SIR - In science (and in other areas) it is bad practice to deduce average behaviour from extreme cases. A particularly colourful example is found in the correspondence from Arno Arrak, who picks the worst possible instance he can think of to justify his antagonism to religious belief. John L. Martin

Department of Physics

King's College London,

Strand, London WC1R 2LS, UK

SIR - I am amused to read that the propensity to religious belief is all the fault of some bit of DNA (Nature 363, 389-390; 1993). Ernst Haeckel, Darwin's greatest evangelist, was of the same mind, boldly asserting that the propensity to mysticism is genetically derived from barbarians and savages. How, one wonders, can such ideas be regarded as evidence of rational thought?

I know - we all know - that the icon on my computer screen is not directly related to the structure of a few semiconductors. It depends on me, my operations, on the electricity supply, on thousands of circuits and memory bits, on the properties of the screen, on magnetic fields and particle beams, on computer languages, and many other things. I also know that my computer is totally incapable of acquiring a propensity to any philosophy --it simply does not have the wherewithal to experience, to learn, to speculate, to make judgements. Maybe one day we will be able to simulate some of these higher faculties; but we can be sure that the processes involved will be of a different order of complexity from the structure of a protein, or a section of DNA.

The new genetic fundamentalism seems to me even more irrational than religious fundamentalism. The latter at least is a sincere attempt to find some meaning and purpose in life, even if, in the opinion of many, it is misguided. If everything we do, or believe, or aim for, is predetermined by bits of DNA, then what value is there in trying to analyse anything, and to make sensible judgements? What point can there be to the scientific quest?

Newton, Faraday and Maxwell, to name just the most obvious, provided us with vital insights that, however embarrassing to the reductionist, came out of their profoundly religious outlook. They were in fact obeying the specifically Christian injunction to "seek, and ye shall find; knock, and it shall be opened unto you". To assume that their science and their religion were distinct and unrelated is, in my opinion, not supported by any evidence or scholarship. Their remarkable work showed the intrinsic consistency in all physical processes - thus confirming the Christian injunction, and sustaining their belief in a meaningful universe.

Once again I would stress that this is an agnostic view. People of all faiths, and no faith, have contributed to the scientific culture. I write this letter to challenge the bias of your journal against religious and esoteric ideas, which is unfair to some of our greatest scientists, and unhelpful in the development of new ideas. In music, in art, in literature, and not least in science, we are all indebted to those of a mystical turn of mind.

\section{John Evans}

81 Cherry Hinton Road,

Cambridge CB1 4BS, UK

\section{Racial science}

SIR - I recently visited the anthropology exhibits in the Museum of Natural History in Vienna. These constitute an understated but quite unequivocal endorsement of Nazi-like racial science. The first room is arranged in continental displays. The main exhibits are a series of single skulls, each presented as representative of a racial type. For instance, in the African section were skulls labelled "Bushman", "Pygmy" and so on; in the European section skulls putatively representative of particular European types, including "Gypsy" but for some reason omitting Jews. In the next room, there is a case displaying two skeletons: one is labelled "Japanese", the other "Indonesian". The small evolutionary exhibit presents three skulls for comparison labelled australopithecine, chimpanzee and "Bushman": the evident message is that the Bushman skull represents a primitive human type.

My first impression was that this travesty had been set up in the 1930s or 1940s, for a considerable proportion of Austrian anthropologists were implicated in Nazi science, and some of the leading figures were enthusiastic Nazis. Perhaps, I thought, it had simply been neglected since, but I was assured that the exhibition had been set up comparatively recently. This is an outrageous display for a major European museum, and I hope that anthropologists throughout the world will join me in an urgent appeal to the museum to close the display, explain to the public why it is both scientifically indefensible and politically and morally offensive, and replace it with a modern exhibition which explains what is now known about human evolution.

\section{Adam Kuper}

(Editor, Current Anthropology)

Department of Human Sciences,

Brunel University.

Uxbridge, Middlesex UB8 3PH, UK

\section{Genetic testing}

SIR - I oppose Ron M. Kagan's letter headed "Justice is not egalitarian" (Nature 363, 578; 1993). Increasing use of genetic screening will demonstrate that everybody carries some genetic disability. If, according to Kagan's optimistic model, all these people would acquire "special skills in high demand" we would witness a cultural improvement of unprecedented scale.

Unfortunately, however, as our German poet Bert Brecht put it: "Yet, such conditions are not found out there" (Doch die Verhältnisse, sie sind nicht so). For this realistic reason, the thoughts of Benno Müller-Hill ought to be taken more seriously. As further reading, I recommend Paul R. Billings et al.: "Discrimination as a consequence of genetic testing" (American Journal of Human Genetics 50, 476-482; 1992).

Ulrich Langenbeck

Theodor Stern-Kai 7 ,

D-60590 Frankfurt am Main,

Germany 